\title{
Systemic lupus erythematosus and genetic variation in the interleukin 1 gene cluster: a population based study in the southeastern United States
}

\author{
C G Parks, G S Cooper, M A Dooley, E L Treadwell, E W St Clair, G S Gilkeson, J P Pandey
}

Ann Rheum Dis 2004;63:91-94. doi: 10.1136/ard.2003.007336

Background: Interleukin (IL) $1 \alpha$ and IL $1 \beta$, and their endogenous receptor antagonist (ILIRa), have been related to the pathology of systemic lupus erythematosus (SLE), but the role of IL1 polymorphisms in the aetiology of SLE is unknown. Objective: To examine polymorphisms at IL $1 \alpha-889(\mathrm{C} \rightarrow \mathrm{T})$, $\mathrm{IL} 1 \alpha+4845(\mathrm{C} \rightarrow \mathrm{T}), \mathrm{IL} 1 \beta-511(\mathrm{C} \rightarrow \mathrm{T}), \mathrm{IL} 1 \beta+3953(\mathrm{G} \rightarrow \mathrm{T})$, and IL1Ra (86 bp VNTR) in a population based study of SLE in North Carolina and South Carolina.

Methods: Genotypes from 230 cases who met ACR classification criteria, and from 275 controls matched for age, sex, and state, were analysed separately for African Americans and whites. Odds ratios (ORs) were estimated by logistic regression models for each locus alone and also after adjusting for polymorphisms at adjacent loci.

Results: An increased risk of SLE for the IL $1 \alpha-889 \mathrm{C} / \mathrm{C}$ genotype compared with carriage of the $-889 \mathrm{~T}$ allele was found in both African Americans (OR=3.1, $p=0.001)$ and whites $(O R=2.9, p=0.005)$. In African Americans, carriage of the IL1 $\beta-511$ T allele was associated with a higher risk of SLE than carriage of the $-511 \mathrm{C} / \mathrm{C}$ genotype $(O R=2.4$, $\mathrm{p}=0.017$ ), independent of variation at ILI $\alpha-889$.

Conclusions: The observed associations support the hypothesis that genetic variation in ILI is involved in the aetiology of SLE and merit further investigation.

1 terleukin (IL) $1 \alpha$ and ILl $\beta$ are proinflammatory cytokines with widespread biological activities, regulated in part by the ILl receptor antagonist (ILIRa). Differences in ILl and ILlRa production have been seen in systemic lupus erythematosus (SLE). ${ }^{12}$ The ILl gene cluster (ILl $\alpha$, ILl $\beta$, ILlRa) is located on a $430 \mathrm{~kb}$ region of chromosome 2 (2q13-21). Polymorphisms include biallelic single nucleotide polymorphisms in ILl $\alpha$ at position $-889(\mathrm{C} \rightarrow \mathrm{T})^{3}$ and in exon 5 at $+4845(\mathrm{G} \rightarrow \mathrm{T}),{ }^{4}$ and in ILl $\beta$ at position $-511(\mathrm{C} \rightarrow \mathrm{T})^{5}$ and in exon 5 at $+3953(\mathrm{C} \rightarrow \mathrm{T}) .{ }^{6}$ Data on allelic variation at these sites in patients with SLE are limited. One study reported that polymorphisms in ILl $\beta(-511$ and +3953) were not associated with SLE. ${ }^{7}$ Variation in the penta-allelic 86 base pair tandem repeat (VNTR) in intron 2 of ILlRa, ${ }^{8}$ specifically the uncommon allele (ILIRa allele 2), has been inconsistently linked to SLE susceptibility. ${ }^{9} 10$

The Carolina Lupus Study is a population based casecontrol study conducted in the southeastern United States. We examined five polymorphic loci in the ILl gene cluster (ILl $\alpha-889$, ILl $\alpha+4845$, ILl $\beta-511$, ILl $\beta+3953$, and the ILIRA 86 base pair VNTR region) with respect to SLE, and estimated the effects of these polymorphisms on SLE individually and after adjusting for variation at all five loci.

\section{PATIENTS AND METHODS}

Study sample

Patients with SLE (diagnosed between January 1995 and July 1999, meeting the 1997 revised American College of Rheumatology (ACR) classification criteria) in 60 counties of North Carolina and South Carolina were referred through 30 community based rheumatologists and four university rheumatology practices. Controls matched for sex and state, identified through state driver's licence records for the 60 study counties, were randomly selected and frequency matched to cases in five-year age groups. Study protocols were approved by the institutional review boards of the National Institute of Environmental Health Sciences and other participating institutions. Details on sample enrolment have been presented previously. ${ }^{11}$ The final sample consisted of 265 cases and 355 controls. Ninety per cent of cases were female, $60 \%$ were African American, and the mean age at diagnosis was 39 years (range 15-81). Thirty per cent of controls were African American, reflecting the racial distribution of the study area.

\section{Genotyping}

Blood specimens were used to obtain DNA from 243 (92\%) cases and $298(84 \%)$ controls. DNA specimens were genotyped for ILl $\alpha-889(\mathrm{C} \rightarrow \mathrm{T}), \operatorname{ILl} \alpha+4845(\mathrm{C} \rightarrow \mathrm{T}), \operatorname{ILl} \beta$ $-511(\mathrm{C} \rightarrow \mathrm{T})$, and $\operatorname{ILl} \beta+3953(\mathrm{G} \rightarrow \mathrm{T})$ biallelic restriction fragment length polymorphisms..$^{3-6}$ Specimens were amplified using polymerase chain reaction and digested with restriction enzymes Fun4Hl, Ncol, Aval, and $\alpha$ Taq, respectively. ILIRa 86 bp VNTR genotypes were determined by polymerase chain reaction based methods. ${ }^{8}$ Alleles were differentiated by visual determination of size relative to known markers (allele $1=4$ repeats, allele $2=2$ repeats, allele $3=5$ repeats, and allele $4=3$ repeats).

\section{Analyses}

Genotypes from 230 cases (144 African-American, 86 white) and 275 controls (73 African-American, 202 white) were examined in parallel analyses for African Americans and whites. Linkage disequilibrium was examined using the estimating haplotypes program (http://linkage.rockefeller. edu/ott/eh.html) $(\alpha=0.05)$. We used the $\chi^{2}$ statistic (Fisher's exact test for cell size $<5)$ to compare genotype frequency in cases and controls at each locus. Odds ratios (ORs) and $95 \%$ confidence intervals (CIs) were calculated by unconditional logistic regression. We did not adjust for multiple comparisons. Models were run for each locus separately, comparing

Abbreviations: $\mathrm{Cl}$, confidence interval; IL, interleukin; ILI Ra, interleukin 1 receptor antagonist; OR, odds ratio; SLE, systemic lupus erythematosus; VNTR, variation in tandem repeat 
the genotypes containing the variant allele with the homozygous wild-type genotype. Independent associations at each locus also were estimated in a model containing all five loci to adjust for potential confounding by linkage disequilibrium. Only the main effects at each locus were examined, except for the interaction of the two promoter polymorphisms (ILl $\alpha-889$ and ILl $\beta-511$ ) with respect to SLE and proteinuria in African Americans. Proteinuria was defined as two or more urine samples containing $\geqslant 3 \mathrm{mg} / \mathrm{ml}$ albumin reported in medical records up to six months after diagnosis.

\section{RESULTS}

Table 1 shows the frequency of ILl $\alpha$, ILl $\beta$, and ILlRa genotypes in patients with SLE and controls. Genotype frequencies were determined to be in Hardy-Weinberg equilibrium, and were significantly different $(p<0.05)$ in African-American and white controls at all loci except ILl $\alpha$ -889 . Genotype frequencies at ILl $\alpha-889$ differed between cases and controls in both African Americans and whites: the ILl $\alpha-889$ C/T genotype was inversely associated with SLE compared with the ILl $\alpha-889 \mathrm{C} / \mathrm{C}$ genotype in single locus models (African Americans $\mathrm{OR}=0.4, \mathrm{p}=0.004$; whites
$\mathrm{OR}=0.5, \mathrm{p}=0.006)$. Carriage of the ILl $\alpha-889$ T allele was inversely associated with SLE in the five locus model (African Americans $\mathrm{OR}=0.3, \mathrm{p}=0.001$; whites $\mathrm{OR}=0.3, \mathrm{p}=0.005$ ) Viewed as a positive risk factor, the ILl $\alpha-889 \mathrm{C} / \mathrm{C}$ genotype was associated with a threefold increased risk of SLE in both African Americans (OR $=3.1$; 95\% CI 1.5 to 6.1, $\mathrm{p}=0.001$ ) and whites (OR $=2.9 ; 95 \%$ CI 1.4 to $6.0, \mathrm{p}=0.005)$ compared with carriage of the ILl $\alpha-889 \mathrm{~T}$ allele. We observed no significant effect for number of copies of ILl $\alpha-889 \mathrm{~T}$. The ILl $\alpha+4845$ polymorphism was not significantly associated with SLE.

In single locus models, the IL1 $\beta-511 \mathrm{C} / \mathrm{T}$ genotype was significantly associated with SLE in African Americans $(\mathrm{OR}=2.5, \mathrm{p}=0.016)$ compared with the $\mathrm{C} / \mathrm{C}$ genotype, and carriage of the ILI $\beta-511$ allele was associated with SLE ( $\mathrm{OR}=2.4, \mathrm{p}=0.017)$ in the five locus model. We observed no significant effect for number of copies of the ILl $\beta-511 \mathrm{~T}$ allele in African Americans, and no association in whites. The IL1 $\beta+3953$ polymorphism was not significantly associated with SLE.

Allelic variation at ILIRa was significantly associated with SLE in African Americans (exact $\mathrm{p}=0.01$ ), driven in part by

Table 1 Frequencies of ILI $\alpha, \operatorname{ILI} \beta$, and ILIRa genotypes and associations with SLE*

\begin{tabular}{|c|c|c|c|c|c|c|}
\hline \multirow[b]{2}{*}{ Genotypes } & \multicolumn{3}{|c|}{ African Americans } & \multicolumn{3}{|l|}{ Whites } \\
\hline & $\begin{array}{l}\text { Cases }(n=144) \\
n(\%)\end{array}$ & $\begin{array}{l}\text { Controls }(n=73) \\
\text { n }(\%)\end{array}$ & OR $(95 \% \mathrm{Cl}) \dagger$ & $\begin{array}{l}\text { Cases }(n=86) \\
n(\%)\end{array}$ & $\begin{array}{l}\text { Controls ( } n=202) \\
n(\%)\end{array}$ & OR $(95 \% \mathrm{Cl})$ \\
\hline \multicolumn{7}{|l|}{ ILI $\alpha-889$} \\
\hline $\mathrm{C} / \mathrm{C}$ & $62(43)$ & $18(25)$ & 1.0 (referent) & $43(50)$ & 68 (34) & 1.0 (referent) \\
\hline $\mathrm{C} / \mathrm{T}$ & $57(40)$ & 43 (59) & $0.4(0.2$ to 0.7$)$ & 32 (37) & 109 (54) & $0.5(0.3$ to 0.8$)$ \\
\hline $\mathrm{T} / \mathrm{T}$ & $25(17)$ & $12(16)$ & $0.6(0.3$ to 1.4$)$ & $11(13)$ & 25 (12) & $0.7(0.3$ to 1.6$)$ \\
\hline \multirow{3}{*}{\multicolumn{3}{|c|}{$\begin{array}{l}\chi^{2}(2 \mathrm{df}) \ddagger \quad 8.4, \mathrm{p}=0.015 \\
\mathrm{C} / \mathrm{T} \text { or } \mathrm{T} / \mathrm{T} v \mathrm{C} / \mathrm{C} \text { (single locus model) } \\
\mathrm{C} / \mathrm{T} \text { or } \mathrm{T} / \mathrm{T} \vee \mathrm{C} / \mathrm{C} \text { (five locus model) }\end{array}$}} & & \multirow{3}{*}{\multicolumn{2}{|c|}{$7.6, p=0.022$}} & \\
\hline & & & $0.4(0.2$ to 0.8$)$ & & & $0.5(0.3$ to 0.8$)$ \\
\hline & & & $0.3(0.2$ to 0.7$)$ & & & $0.3(0.2$ to 0.7$)$ \\
\hline \multicolumn{7}{|l|}{$1 L 1 \alpha+4845$} \\
\hline$G / G$ & 96 (67) & $54(74)$ & 1.0 (referent) & $45(52)$ & 95 (47) & 1.0 (referent) \\
\hline $\mathrm{G} / \mathrm{T}$ & 39 (27) & $18(25)$ & $1.2(0.6$ to 2.4$)$ & $27(31)$ & 83 (41) & $0.7(0.4$ to 1.2$)$ \\
\hline $\mathrm{T} / \mathrm{T}$ & $8(6)$ & 1 (1) & - & $14(16)$ & 24 (12) & $1.2(0.6$ to 2.6$)$ \\
\hline$\chi^{2}(2 d f)$ & $2.5, p=0.28$ & & & \multirow{3}{*}{\multicolumn{2}{|c|}{$2.1, p=0.26$}} & \\
\hline \multirow{2}{*}{\multicolumn{3}{|c|}{$\begin{array}{l}G / T \text { or } T / T \vee G / G \text { (single locus model) } \\
G / T \text { or } T / T \vee G / G \text { (five locus model) }\end{array}$}} & $1.4(0.7$ to 2.6$)$ & & & $0.8(0.5$ to 1.3$)$ \\
\hline & & & $1.8(0.9$ to 3.5$)$ & & & $1.3(0.6$ to 2.7$)$ \\
\hline \multicolumn{7}{|l|}{$1 L 1 \beta-511$} \\
\hline $\mathrm{C} / \mathrm{C}$ & $23(16)$ & 21 (29) & 1.0 (referent) & $41(48)$ & $89(44)$ & 1.0 (referent) \\
\hline $\mathrm{C} / \mathrm{T}$ & 73 (51) & 27 (37) & 2.5 (1.2 to 3.8$)$ & $36(42)$ & 87 (43) & $0.9(0.5$ to 1.5$)$ \\
\hline $\mathrm{T} / \mathrm{T}$ & $48(33)$ & 25 (34) & $1.8(0.8$ to 3.8$)$ & $9(10)$ & 26 (13) & $0.8(0.3$ to 1.7$)$ \\
\hline$\chi^{2}(2 d f)$ & $5.9, p=0.052$ & & & \multirow{3}{*}{\multicolumn{2}{|c|}{$0.48, p=0.79$}} & \\
\hline \multirow{2}{*}{\multicolumn{3}{|c|}{$\begin{array}{l}\mathrm{C} / \mathrm{T} \text { or } \mathrm{T} / \mathrm{T} \vee \mathrm{C} / \mathrm{C} \text { (single locus model) } \\
\mathrm{C} / \mathrm{T} \text { or } \mathrm{T} / \mathrm{T} \vee \mathrm{C} / \mathrm{C} \text { (five locus model) }\end{array}$}} & 2.1 (1.1 to 4.2$)$ & & & $0.9(0.5$ to 1.4$)$ \\
\hline & & & $2.4(1.2$ to 4.9$)$ & & & $0.8(0.4$ to 1.3$)$ \\
\hline \multicolumn{7}{|l|}{$1 L 1 \beta+3953$} \\
\hline $\mathrm{C} / \mathrm{C}$ & 111 (77) & $61(85)$ & 1.0 (referent) & $49(57)$ & $121(60)$ & 1.0 (referent) \\
\hline $\mathrm{C} / \mathrm{T}$ & 32 (22) & $10(14)$ & $1.8(0.8$ to 3.8$)$ & $31(36)$ & 67 (33) & $1.1(0.7$ to 2.0$)$ \\
\hline $\mathrm{T} / \mathrm{T}$ & $1(1)$ & 1 (1) & - & $6(7)$ & $13(6)$ & 1.1 (0.4 to 3.2$)$ \\
\hline$\chi^{2}(2 d f)$ & $2.3, p=0.31$ & & & \multicolumn{2}{|l|}{$0.26, p=0.88$} & \\
\hline \multicolumn{3}{|c|}{$\mathrm{C} / \mathrm{T}$ or $\mathrm{T} / \mathrm{T} \vee \mathrm{C} / \mathrm{C}$ (single locus model) } & $1.6(0.8$ to 3.5$)$ & & & $1.1(0.7$ to 1.9$)$ \\
\hline $\mathrm{C} / \mathrm{T}$ or $\mathrm{T} / \mathrm{T}$ & (five locus model) & & $1.6(0.7$ to 3.5$)$ & & & $1.6(0.8$ to 3.0$)$ \\
\hline \multicolumn{7}{|l|}{ ILIRa VNTR } \\
\hline $1 / 1$ & $130(90)$ & $63(87)$ & 1.0 (referent) & $63(73)$ & $160(79)$ & 1.0 (referent) \\
\hline $1 / 2$ & $6(4)$ & $3(4)$ & $1.0(0.2$ to 4.0$)$ & 12 (14) & $18(9)$ & $1.7(0.8$ to 3.7$)$ \\
\hline $2 / 2$ & $1(1)$ & $0(0)$ & - & $8(9)$ & $15(7)$ & $1.4(0.6$ to 3.4$)$ \\
\hline $1 / 3$ & $1(1)$ & $6(8)$ & - & $3(3)$ & 7 (3) & $1.1(0.3$ to 4.3$)$ \\
\hline $3 / 3$ & $0(0)$ & $0(0)$ & - & $0(0)$ & $2(1)$ & - \\
\hline $1 / 4$ & $6(4)$ & $0(0)$ & - & $0(0)$ & $0(0)$ & - \\
\hline$\chi^{2}(4 d f)$ & $12.2, p=0.016$ & & & \multirow{3}{*}{\multicolumn{2}{|c|}{$2.9, p=0.58$}} & \\
\hline \multirow{2}{*}{\multicolumn{3}{|c|}{$\begin{array}{l}1 / 2 \text { or } 2 / 2 \text { v other genotypes (single locus model) } \\
1 / 2 \text { or } 2 / 2 v \text { other genotypes (five locus model) }\end{array}$}} & $1.2(0.3$ to 4.7$)$ & & & $1.6(0.8$ to 3.0$)$ \\
\hline & & & $0.8(0.2$ to 3.2$)$ & & & $1.7(0.9$ to 3.4$)$ \\
\hline
\end{tabular}

*Frequencies based on total number shown except as follows. In African Americans: IL $1 \alpha+4845$ based on 143 patients and IL1 $\beta+3953$ based on 72 controls. In whites: ILI $\beta+3953$ based on 201 controls; TOR (odds ratios) and $95 \% \mathrm{Cl}$ (confidence intervals) were derived from logistic regression models comparing the homozygous wild-type genotype with other genotypes. Values are derived from single locus models except where shown for the five locus models. Odds ratios and confidence intervals are not presented for genotypes with fewer than three cases or controls; $\pm \chi^{2}$ statistic shown. Fisher's exact statistic also calculated for ILIRa $(p=0.01$ in African Americans and $p=0.61$ in whites), and for ILI $\alpha+4845(p=0.33)$ and IL1 $\beta+3953(p=0.28)$ in African Americans. 
Table 2 Frequency of estimated haplotypes including five polymorphic loci within the ILl gene cluster in African-American and white CLU study participants*

\begin{tabular}{|c|c|c|c|c|c|c|c|c|}
\hline \multicolumn{5}{|c|}{ Estimated haplotypes } & \multicolumn{4}{|c|}{ Percentage } \\
\hline \multicolumn{2}{|l|}{$\operatorname{ILl} \alpha$} & \multicolumn{2}{|l|}{ ILI } & \multirow{2}{*}{$\begin{array}{l}\text { ILIRa } \\
\text { VNTR }\end{array}$} & \multicolumn{2}{|c|}{ African Americans } & \multicolumn{2}{|l|}{ Whites } \\
\hline-889 & +4845 & -511 & +3953 & & Cases & Controls & Cases & Controls \\
\hline C & $G$ & $\mathrm{~T}$ & $\mathrm{C}$ & 1 & 32 & 27 & 16 & 19 \\
\hline C & $G$ & C & C & 1 & 20 & 24 & 30 & 28 \\
\hline C & G & C & $\mathrm{T}$ & 1 & 0 & 0 & 5 & 1 \\
\hline C & G & $\mathrm{T}$ & C & 2 & 1 & 1 & 8 & 4 \\
\hline $\mathrm{T}$ & G & $\mathrm{T}$ & C & 1 & 12 & 13 & 2 & 2 \\
\hline $\mathrm{T}$ & $\mathrm{T}$ & C & $\mathrm{T}$ & 1 & 3 & 0 & 15 & 16 \\
\hline $\mathrm{T}$ & G & C & C & 1 & 8 & 12 & 2 & 5 \\
\hline $\mathrm{T}$ & G & $\mathrm{T}$ & $\mathrm{T}$ & 1 & 2 & 5 & 0 & 0 \\
\hline $\mathrm{T}$ & $\mathrm{T}$ & C & C & 1 & 5 & 6 & 6 & 6 \\
\hline
\end{tabular}

carriage of ILIRa allele 3, which was significantly less common in African-American cases than in controls (exact $\mathrm{p}=0.006)$ and inversely associated with SLE (OR $=0.1,95 \%$ CI 0.0 to 0.7$)$. Variation at ILlRa was not significantly associated with SLE in whites, though ILIRa allele 2 was more common in patients with SLE than controls $(\mathrm{OR}=1.7$, $\mathrm{p}=0.102)$.

Table 2 shows the frequency of estimated haplotypes. There was little evidence of linkage disequilibrium among the five loci in African Americans except between ILl $\alpha-889$ and +4845 in both cases and controls (controls, $\mathrm{p}<0.005$; cases, $\mathrm{p}<0.0001$ ). In whites, there was significant linkage disequilibrium for most pairwise comparisons.

None of the genotypes were independently associated with proteinuria, although ILlRa allele 2 was non-significantly raised in white cases with proteinuria $(25 \% v 9 \%$; OR $=3.3$, $\mathrm{p}=0.077$ ). In African Americans no interaction was seen between ILl $\alpha-889$ and ILl $\beta-511$ genotypes for overall risk of $\operatorname{SLE}(p=0.938)$, but a highly significant interaction $(p=0.002)$ was seen for risk of proteinuria. Paradoxically, the combined ILl $\alpha-889$ C/C, ILI $\beta-511$ genotype was positively associated with risk of SLE (OR $=2.4,95 \%$ CI 1.2 to 5.1; $\mathrm{p}=0.019)$, but inversely associated with proteinuria $(\mathrm{OR}=0.4,95 \%$ CI 0.2 to $0.9 ; \mathrm{p}=0.027)$.

\section{DISCUSSION}

As far as we know this is the first study to simultaneously examine these five loci with respect to SLE and to report an association between allelic variation at ILl $\alpha-889$ and SLE. In both African-Americans and whites, the ILl $\alpha-889 \mathrm{C} / \mathrm{C}$ genotype was associated with a threefold higher risk of SLE than carriage of the T allele. The ILl $\alpha-889 \mathrm{C} / \mathrm{C}$ genotype has been associated with other inflammatory and autoimmune diseases, including scleroderma. ${ }^{12}$ In African Americans, carriage of the IL1 $\beta-511$ T allele was also associated with increased risk of SLE, even after adjusting for variation at IL $1 \alpha-889$. A previous study in China reported no association between this locus and SLE. ${ }^{7}$ We did not observe a dose effect for the number of copies of the ILl $\alpha-889 \mathrm{~T}$ or ILl $\beta-511 \mathrm{~T}$ alleles. However, repeating this study with a larger sample size would provide greater power to detect such a relationship.

These two ILl promoter polymorphisms may affect ILl production. The IL $1 \alpha-889 \mathrm{C} / \mathrm{C}$ genotype has been associated with significantly lower transcriptional activity of the ILl $\alpha$ gene and lower levels of ILl $\alpha$ in plasma compared with the $\mathrm{T} / \mathrm{T}$ genotype. ${ }^{13}$ Variation in ILl $\alpha$ may also affect the production of ILl $\beta$ : in healthy Finnish subjects, plasma ILl $\beta$ was lower in those with ILl $\alpha-889 \mathrm{C} / \mathrm{C}$ than in those with the T/T genotype. ${ }^{14}$ The IL1 $\beta-511$ polymorphism, linked to the ILI $\beta-31$ TATA box polymorphism that affects DNAprotein interactions in vitro, ${ }^{15}$ may reflect potential for altered levels of gene expression. There has been little indication of an effect of IL1 $\beta-511$, however, on IL1 $\beta$ levels in vivo. ${ }^{14}$

Our results do not support the hypothesis that IL1Ra allele 2 affects the risk of SLE. However, our ability to detect an association might be limited by the low frequency of this allele in our study group, especially among African Americans. The inconsistent findings for this locus might also be due to differences in linkage disequilibrium with other relevant loci in the ILl gene cluster. ${ }^{9}{ }^{10}$ ILl Ra allele 2 has been associated with increased production of IL1Ra and ILl $\beta$, and decreased production of $\operatorname{ILl} \alpha,{ }^{16}$ suggesting that these genes should be studied collectively.

We considered these analyses to be useful for generating a hypothesis and did not adjust for multiple comparisons. However, a post hoc analysis yielded a highly significant $(p<0.0001)$ overall association between ILl $\alpha-889$ C/C and SLE that remained significant $(p<0.0005)$ after Boneferroni adjustment. Our confidence in the association between the ILl $\alpha-889$ C/C genotype and SLE is increased by the similar magnitude of effect in African-Americans and whites despite different racial patterns of linkage disequilibrium across the ILl gene cluster. Population based sampling of controls can help to minimise the effects of selection bias and population stratification. The proportion of African-American controls in this sample reflected the racial distribution in the study area based on census estimates, resulting in fewer AfricanAmerican controls than white controls or African-American cases. None the less, the observed associations in African Americans were statistically significant.

In conclusion, polymorphisms in two ILl gene promoter regions were significantly associated with SLE in this study sample. Variation at both loci may affect ILl and ILIRa production, supporting the hypothesis that altered or imbalanced ILl production may affect the risk of developing SLE.

\section{ACKNOWLEDGEMENTS}

Special thanks and appreciation are extended to the doctors who participated in the Carolina Lupus Study, and to Ms Louise Weston who performed most of the laboratory analyses.

This work was funded in part by an NIH Intramural Research Training Award and the US Department of Energy cooperative agreement DE-FC02-02CH11109. The Carolina Lupus Study was supported by the Intramural Research Program of the NIEHS and the National Center for Minority Health and Health Disparities of the NIH. 


\section{Authors' affiliations}

C G Parks, G S Cooper, National Institute of Environmental Health

Sciences, NIH, DHHS, Durham, NC, USA

M A Dooley, University of North Carolina Medical School, Chapel Hill,

NC, USA

E L Treadwell, East Carolina University School of Medicine, Greenville, NC, USA

E W St Clair, Duke University Medical Center, Durham, NC, USA G S Gilkeson, J P Pandey, Medical University of South Carolina, Charleston, SC, USA

Correspondence to: Dr C G Parks, Epidemiology Branch, A3-05, NIEHS, NIH-DHHS, PO Box 12233, Durham, North Carolina, USA; parks@niehs.nih.gov

Accepted 28 April 2003

\section{REFERENCES}

1 Rus V, Atamas SP, Shustova V, Luzina IG, Selaru F, Magder LS, et al. Expression of cytokine- and chemokine-related genes in peripheral blood mononuclear cells from lupus patients by cDNA array. Clin Immunol 2002; 102:283-90.

2 Andersen LS, Petersen J, Svenson M, Bendtzen K. Production of IL-1 beta, IL-1 receptor antagonist and IL-10 by mononuclear cells from patients with SLE. Autoimmunity 1999;30:235-42.

3 McDowell TL, Symons JA, Ploski R, Forre O, Duff GW. A genetic association between juvenile rheumatoid arthritis and a novel interleukin-1 alpha polymorphism. Arthritis Rheum 1995:38:221-8.

4 van den Velden PA, Reitsma PH. Amino acid dimorphism in ILIA is detectable by PCR amplification. Hum Mol Genet 1993;2:1753.

5 di Giovine FS, Takhsh E, Blakemore Al, Duff GW. Single base polymorphism at -511 in the human interleukin-1 beta gene (IL1 beta). Hum Mol Genet 1992; 1:450.
6 Pociot F, Molvig J, Wogensen L, Worsaae H, Nerup J. A Taql polymorphism in the human interleukin-1 beta (IL-1 beta) gene correlates with IL-1 beta secretion in vitro. Eur J Clin Invest 1992;22:396-402.

7 Huang CM, Wu MC, Wu JY, Tsai FJ. Lack of association of interleukin-1 beta gene polymorphisms in Chinese patients with systemic lupus erythematosus. Rheumatol Int 2002;21:173-5.

8 Tarlow JK, Blakemore Al, Lennard A, Solari R, Hughes HN, Steinkasserer A, et al. Polymorphism in human IL-1 receptor antagonist gene intron 2 is caused by variable numbers of an $86-b p$ tandem repeat. Hum Genet 1993:91:403-4.

9 Huang CM, Wu MC, Wu JY, Tsai FJ. Interleukin-1 receptor antagonist gene polymorphism in Chinese patients with systemic lupus erythematosus. Clin Rheumatol 2002;21:255-7.

10 D'Alfonso S, Rampi M, Bocchio D, Colombo G, Scorza-Smeraldi R, Momigliano-Richardi P. Systemic lupus erythematosus candidate genes in the Italian population: evidence for a significant association with interleukin-10. Arthritis Rheum 2000;43:120-8.

11 Cooper GS, Dooley MA, Treadwell EL, St Clair EW, Gilkeson GS. Hormonal and reproductive risk factors for development of systemic lupus erythematosus: results of a population-based, case-control study. Arthritis Rheum 2002;46:1830-9

12 Kawaguchi Y, Tochimoto A, Ichikawa N, Harigai M, Hara M, Kotake S, et al. Association of IL1A gene polymorphisms with susceptibility to and severity of systemic sclerosis in the Japanese population. Arthritis Rheum 2003;48: 186-92.

13 Dominici R, Cattaneo M, Malferrari G, Archi D, Mariani C, Grimaldi LM, et al. Cloning and functional analysis of the allelic polymorphism in the transcription regulatory region of interleukin-2 alpha. Immunogenetics 2002;54:82-6

14 Hulkkonen J, Laippala P, Hurme M. A rare allele combination of the interleukin-1 gene complex is associated with high interleukin-1 beta plasma levels in healthy individuals. Eur Cytokine Netw 2000;11:251-5.

15 El-Omar EM, Carrington M, Chow WH, McColl KE, Bream JH, Young HA et al. The role of interleukin-1 polymorphisms in the pathogenesis of gastric cancer. Nature 2001;412:99.

16 Hurme M, Santtila S. IL-1 receptor antagonist (IL-1Ra) plasma levels are coordinately regulated by both IL-1Ra and IL-1 beta genes. Eur J Immunol 1998;28:2598-602. 